\title{
Selection of Prospective Drought-Tolerant Cocoa Hybrids Based on Additive Main Effect and Multiplicative Interaction Analyses
}

\author{
Bayu Setyawan ${ }^{1 *}$ and Agung Wahyu Susilo ${ }^{1)}$ \\ ${ }^{1)}$ Indonesian Coffee and Cocoa Research Institute, Jl. PB. Sudirman No. 90, Jember, Indonesia \\ ${ }^{*}$ Corresponding author: setyawanbayu45@gmail.com \\ Received: 13 March 2017 / Accepted: 27 June 2017
}

\begin{abstract}
Global warming impact in increasing temperature and becomes threat for cocoa production because growth of cocoa depends on the amount of water available in the environment. The objective of this study was to describe cocoa hybrid that may potentially be developed as drought-resistant cocoa hybrid. The study used 14 types of cocoa hybrids and ICCRI $06 \mathrm{H}$ as control. Those plants were approximately 4 years old and the hybrids were planted in Sumber Asin Experimental Station and Kendeng Lembu Plantation. The variables being observed to evaluate 2015 El-Nino effect were percentage of growing plants, tree diameter, jorquette height, flush and flower intensity in 2016. Analysis of variance, correlation and additive main effect and multiplicative interaction (AMMI) biplot were used to find out which hybrids were potentially drought-resistant. The finding showed that there was significant interaction between the genotypes (hybrids) and environment towards the percentage of growing plants, tree diameter, flush and flower intensity. The correlation between the variables showed that there was significant, negative correlation between the percentage of growing plants and height; even though there was significant correlation between the two, it was quite low. There was significant correlation between the tree diameter and the jourquette height while there was not any between the tree diameter and the percentage of growing plants. The AMMI analysis classified the drought tolerant hybrids into two groups, (1) cocoa hybrids adaptive to both normal as well as the temperature and water scarcity (drought), was ICCRI $03 \times$ KW 617, and (2) drought tolerance cocoa hybrids, was KW 516 x KW 617.
\end{abstract}

Keywords: Hybrid, drought-tolerant, AMMI, vegetative growth

\section{INTRODUCTION}

The issue for cocoa cultivation in the future is climate change as it continues decreasing cocoa production every year (Oyekale et al., 2009). Dry climate is the more serious challenge because cocoa plantation depends heavily on water supply, particularly rainfall (Amos \& Thompson, 2015). Cultivation technology, one that speci- fies in dry marginal land, should develop plants that are capable of adapting to dry land. Developing drought tolerant species is an alternative to anticipate the impacts of climate change as well as indicator that the technology can facilitate expansion of cocoa plantation to dry areas. It is expected that drought tolerant be able to maintain, or even improve, cocoa production due to its ability to survive high temperature (Amedie, 2013). 
Cocoa plants in Indonesia are developed from generative and vegetative propagation, but the majority of them are the result of generative propagation using hybrid seeds (Wahyudi et al., 2015). Hybrids are plant species coming from homozygous crossbreed seeds in order that the progeny has heterosis effect. It takes quite long time for homozygous seed of perennial crops to assemble a hybrid; however, it takes significant amount of time and specific method, chromosome doubling in the haploid of the seeds, to obtain homozygous seed from the perennial crops (Prabha et al., 2012). The use of hybrids in cocoa plants is based on plant populations rather than individual plants, so the traits observed in cocoa hybrids is the characteristics of the crossbred population.

Farmers prefer to use seeds for nursery and cultivation and therefore, $90 \%$ of cocoa grown in plantation in Indonesia comes from cocoa seeds (Ditjenbun, 2015). The main objective of developing qualified cocoa hybrids is creating cocoa species resistant to vascularstreak dieback (VSD) disease, and the result of the development are ICCRI $06 \mathrm{H}$. This hybrids is VSD and drought tolerant (Susilo, 2011; Susilo et al., 2016). Generative propagated plants generally have more roots and tap roots that help the plants to survive drought (Paez-Garcia et al., 2015). Droughttolerant plants will have good vegetative and generative growth although they are grown in places where water are scarce (Muthuramu et al., 2011). Qualified cocoa hybrid is also used as rootstock in clonal cocoa multiplication using budding and grafting method. Currently, cocoa hybrid development focuses on developing cocoa hybrids tolerant to abiotic environmental stress, more particularly drought as well as major pests and diseases.

Developing drought-tolerant cocoa hybrids is one of the Indonesian Coffee and Cocoa Research Institute targets of which purpose is to develop cocoa plantation in dry areas. Crossbreeding process between clonal seeds have resulted in several cocoa hybrids; these hybrids were planted in multilocations with dry areas in order to get overview about what dry climate was (Susilo et al., 2016). El Nino took place in 2015 (BMKG, 2015) is a threat to the growth of the cocoa hybrids because it causes maximum drought in the field. The multivariate analysis using AMMI reveals performance stability of the cocoa hybrids as the bases for selecting droughttolerant cocoa hybrids. AMMI is an effective method for analyzing crop stability compared to variance and principal component analysis (Suwarto \& Nasrullah, 2014). The study explains the result of AMMI analysis towards cocoa hybrids performance during water scarcity (drought) stress as the basis for preliminary selection of drought-tolerant cocoa hybrids.

\section{MATERIALS AND METHODS}

The selection of drought-tolerant cocoa hybrids was started by testing 14 hybrids from clonal crossbreeding and ICCRI 06H as control (Table 1). They were planted in two locations, Sumber Asin Experimental Station in Malang (550 m asl.) and Kendeng Lembu Plantation of PTPN XII in Banyuwangi (200 m asl.); both locations have rainfall type $\mathrm{C}$ based on Schmidt \& Fergusson classification. The experiments used complete randomized block design with three blocks as replications and 24 cocoa plants were planted in each plot. The cocoa hybrids were planted in Sumber Asin Experimental Station in 2011 and those were planted in Kendeng Lembu Plantation in 2012. When some of the cocoa plants died, new cocoa plant was grown to meet the population requirement. Leucaena sp. was planted as shade for the cocoa hybrids. 
Evaluation on the performance of the drought-tolerant cocoa hybrids was conducted by observing the following variables, namely percentage of growing plants, tree diameter, jorquette height, flush and flower intensity. The observations were conducted in 2015 and 2016.

Table 1. List of crossing combinations between clonal parents and codes of hybrids used in this multi locations experiment

\begin{tabular}{l}
\hline Crossing combinations of the selected parental clones \\
\hline ICCRI 03 x KW 617 \\
ICCRI 03 x KW 516 \\
ICCRI 03 x Sulawesi 3 \\
ICCRI 03 x Sulawesi 1 \\
KW 617 x ICCRI 03 \\
KW 617 x KW 516 \\
KW 617 x Sulawesi 3 \\
KW 617 x Sulawesi 1 \\
KW 516 x ICCRI 03 \\
KW 516 x KW 617 \\
KW 516 x Sulawesi 3 \\
KW 516 x Sulawesi 1 \\
Sulawesi 3 X KKM 22 \\
KKM 22 x Sulawesi 3 \\
TSH 858 x Sulawesi 1 (ICCRI 06H)
\end{tabular}

Multiple variance analysis was conducted to investigate the effects of location, hybrid as well as interaction between hybrid and location. The following procedure was AMMI analysis which according to Gauch cit. Rashidi et al. (2013) described pattern of interaction between the hybrid and environment so specific adaptability of the hybrids can be identified.

The AMMI analysis using the SAS 9.4 for Windows and the 2010 Microsoft Excel resulted in the following equation.

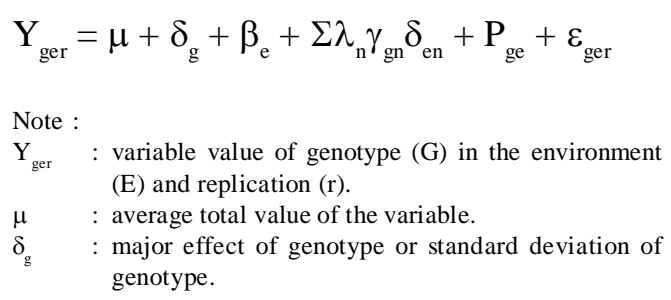

$\beta_{\mathrm{e}} \quad$ : major effect of environment or standard deviation of environment.

$\lambda_{\mathrm{n}} \quad:$ singular value for the $\mathrm{n}^{\text {th }}$ IPCA axis (n: the number of PCA axis on AMMI model).

$\gamma_{\mathrm{gn}} \quad:$ genotype eigen vector value for the $\mathrm{n}^{\text {th }}$ IPCA axis.

$\mathrm{P}_{\mathrm{ge}}$ : effect of interaction between genotype and environment.

$\varepsilon_{\text {ger }} \quad:$ residual and error (if the experiment was repeated).

Pearson correlation analysis was conducted to identify the correlation between the variables (Hauke \& Kossowski, 2011).

\section{RESULTS AND DISCUSSION}

Initial growth phase of the plant is an important phase that should be paid into attention to especially when it is grown in dry land with very limited water. Getting very limited water during the initial growth phase will inhibit vegetative growth (Farooq et al., 2009). The effect of hybrids (genotypes), location, and interaction showed there was significant effect towards the growing percentage, tree diameter, and flush intensity, while location had more significant influence towards the jorquette height and interaction between hybrids and their location had significant influence on flower intensity (Table 2). Interaction between genetic and environment was relativelly change in the performance of genes in different environments; it happened due to the complex process of phenocopy, genocopy, and epigenetic factors (Baye et al., 2011). The effect of hybrids showed that different genotypes in a particular population would show different expressions because certain gene would encode the phenotypic traits corresponding to their genetic code (Flori et al., 2009). The effect of the location showed effect of environmental factors (climate), more particularly the availability of water and temperature affected the growth and development of plants (Nohong \& Nompo, 2015). The significant interaction showed that hybrid expressions were closely related to environmental conditions where 
the plants were grown. The interaction between genotype and environment showed that there was hybrid population suitable (stable) in all conditions and there were certain hybrid populations adaptive to a particular location only.

Based on the genotypic hybrid average, one was able to describe potential tolerance towards drought. The crossbreeding between ICCRI $03 x$ Sulawesi 3 was the hybrid with the highest growing percentage in both locations. Other hybrids that also had high growing percentage were mostly the yield of KW 516. The growing percentage measured the ability of plants to survive in growing environmental conditions; plants with high growing percentage had potentials to be developed as genotypes that may survive dry conditions in each loca- tion. Initial phase of plant growth in the field was a critical condition of plants to grow into productive plants; lack of water during the phase inhibited the plants growth (Carr \& Lockwood, 2011). The hybrids that survive during the preliminary growing stage were candidates for drought-tolerant genotypes (Susilo et al., 2016).

The result of the correlation analysis showed strong correlation between height of jorquette and percentage of growing cocoa hybrids. The correlation coefficient was -0.2598 indicating that the higher the jorquette was, the fewer the growing plants were. Even though the correlation coefficient showed significant correlation, the value was low; which indicated that correlation between two

Table 2. Mean square of combined variance of analysis for cocoa hybrid growing variables

\begin{tabular}{lrccccc}
\hline \multirow{2}{*}{ Source of variance } & df & \multicolumn{5}{c}{ Mean square } \\
\cline { 3 - 7 } & & Alive percentage & Tree diameter & Jorquette height & Flush intensity & Flower intensity \\
\hline Block & 2 & $346.21^{\text {ns }}$ & $89.51^{\text {ns }}$ & $82.42^{\text {ns }}$ & $0.11^{\text {ns }}$ & $1.01^{* *}$ \\
Hybrid & 14 & $303.80^{*}$ & $163.37^{*}$ & $227.86^{\text {ns }}$ & $0.34^{*}$ & $0.18^{\text {ns }}$ \\
Location & 1 & $1678.04^{* *}$ & $9771.51^{* *}$ & $1099.84^{*}$ & $0.99^{*}$ & $0.43^{\text {ns }}$ \\
Hybrid*Location & 14 & $669.44^{* *}$ & $163.55^{*}$ & $362.07^{\text {ns }}$ & $0.35^{*}$ & $0.27^{*}$ \\
Error & 57 & $131.57^{*}$ & $73.16^{*}$ & $234.44^{*}$ & $0.14^{*}$ & 0.14 \\
\hline
\end{tabular}

Notes: $\quad * *=$ significant at $99 \% ; *=$ significant at $95 \% ; \mathrm{ns}=$ not significant

Table 3. Growth variables of cocoa hybrids in two locations

\begin{tabular}{|c|c|c|c|}
\hline Hybrid & Alive percentage & Tree diameter $(\mathrm{cm})$ & Jorquette height $(\mathrm{cm})$ \\
\hline ICCRI 03 x KW 617 & 84.03 a-e & $50.25 \mathrm{c-f}$ & $93.02 \mathrm{a}-\mathrm{b}$ \\
\hline ICCRI 03 x KW 516 & $88.19 a-b$ & $52.60 \mathrm{~b}-\mathrm{f}$ & $89.50 a-b$ \\
\hline ICCRI 03 x Sulawesi 3 & $90.97 \mathrm{a}$ & $50.96 \mathrm{c}-\mathrm{f}$ & $87.22 \mathrm{~b}$ \\
\hline ICCRI 03 x Sulawesi 1 & 85,28 a-d & $52.93 \mathrm{~b}-\mathrm{f}$ & $100.16 a-b$ \\
\hline KW 617 x ICCRI 03 & $72.22 \mathrm{~d}-\mathrm{f}$ & $48.21 \mathrm{e}-\mathrm{f}$ & $105.55 \mathrm{a}$ \\
\hline KW $617 \times$ KW 516 & $81.94 \mathrm{aff}$ & 58.98 a-d & $101.75 \mathrm{a}-\mathrm{b}$ \\
\hline KW 617 x Sulawesi 3 & $75.00 \mathrm{~b}-\mathrm{f}$ & 56.05 a-e & $88.53 \mathrm{a}-\mathrm{b}$ \\
\hline KW 617 x Sulawesi 1 & $68.70 \mathrm{f}$ & $49.50 \mathrm{~d}-\mathrm{f}$ & $86.80 \mathrm{~b}$ \\
\hline KW 516 x ICCRI 03 & $88.19 a-b$ & $44.78 \mathrm{f}$ & $94.74 a-b$ \\
\hline KW 516 x KW 617 & $80.56 \mathrm{aff}$ & $61.44 a-b$ & $105.58 \mathrm{a}$ \\
\hline KW 516 x Sulawesi 3 & 70.84 e-f & $57.31 \mathrm{a}-\mathrm{e}$ & $93.96 \mathrm{a}-\mathrm{b}$ \\
\hline KW 516 x Sulawesi 1 & $74.31 \mathrm{c}-\mathrm{f}$ & $52.61 \mathrm{~b}-\mathrm{f}$ & $98.19 \mathrm{a}-\mathrm{b}$ \\
\hline Sulawesi 3 X KKM 22 & $74.31 \mathrm{c}-\mathrm{f}$ & $59.82 \mathrm{a}-\mathrm{c}$ & $94.92 a-b$ \\
\hline KKM 22 x Sulawesi 3 & $87.50 \mathrm{a}-\mathrm{c}$ & $63.06 \mathrm{a}$ & $99.19 a-b$ \\
\hline TSH 858 x Sulawesi 1 (ICCRI 06H) & 77.78 a-f & $58.56 \mathrm{a}-\mathrm{d}$ & $99.33 a-b$ \\
\hline
\end{tabular}

Notes: Figures in the same column followed by the same letter(s) are not significantly different at $95 \%$. 
Table 4. Correlation analysis between cocoa vegetative variables

\begin{tabular}{|c|c|c|c|}
\hline & Alive percentage & Tree diameter & Jorquette height \\
\hline Alive percentage & 1 & & \\
\hline Tree diameter & 0.0219 & 1 & \\
\hline Jorquette height & $-0.2598^{*}$ & $0.3935^{* *}$ & 1 \\
\hline
\end{tabular}

variables may be neglected (Mukaka, 2012). There was not any significant correlation between the tree diameter and the percentage of the growing plants, however, there was significant correlation between the tree diameter and the jorquette height (the correlation coefficient was 0.3935 or categorized as low). Based on the previous study (Anita-Sari \& Susilo, 2012) the correlation coefficient between diameter of the tree and the height of plants from the grafting was more or less the same (0.3600). High tree diameter would result in higher plants; the correlation between the height of the jorquette and the tree diameter was categorized as low. Growth ring was associated to growth of a plant, particularly that related to temperature and drought (Torbenson, 2015). Plants grown in a place where water supply was adequate had higher tree diameter compared to those grown in a place where water was scarce (Anjum et al., 2011).

AMMI 1 (interaction with the average of the variables) biplot in Figure 1 showed pattern of interaction between hybrids and location where they were grown in several variables. Based on Figure 1, the genotypes grown in both plantation of which position were closed to the axis had good stability, while the genotypes of which positions were close to each of the environment showed specific ability to the environment in which they were grown (Mc Dermott \& Coe, 2012). Kendeng Lembu was selected as more suit- able environment for the hybrids because had higher rainfall than Sumber Asin. The hybrids, ICCRI 03 x KW 617, KW 516 x Sulawesi 3, and KW 516 x Sulawesi 1, had good stability when they were grown in both locations; the genotypes of which position were closer to the axis were the ones with lower interaction scores, and therefore, it may be said that these were stable genotypes (Muthuramu et al., 2011). The hybrids with high adaptability despite of being grown in harsher environment (Sumber Asin) were KW 617 x KW 516, KW 516 x KW 617, and Sulawesi 3 x KKM 22 crossbreeding. Genotypes closer to specific environmental point were those with good adaptability to the environment (Thangavel et al., 2011). The six hybrids may potentially be developed and used for cocoa farming in dry land.

Based on the AMMI 1 analysis, the six hybrids mentioned earlier had average growing percentage compared to other hybrids, but they had higher drought tolerance represented by their level of stability and adaptability towards the environment where they were grown. Until recently, the government has yet released drought-tolerant clone/hybrids. Hence, it is expected that the findings of the study become reference on which cocoa hybrids are drought-tolerant ones and which of them that can potentially carry droughttolerant properties (KW 617, KW 516, and Sulawesi 3). 
AMMI 1 Biplot for tree diameter

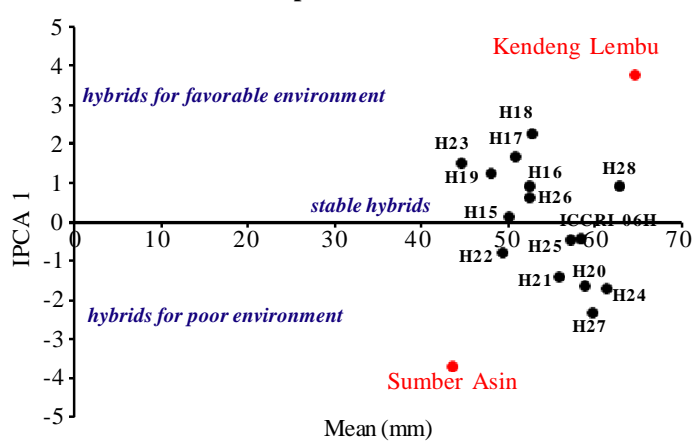

AMMI 1 Biplot for flush intensity

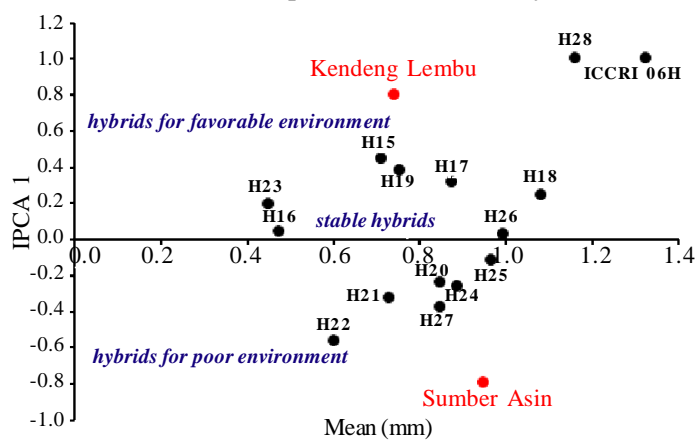

AMMI 1 Biplot for percentage of growing plant

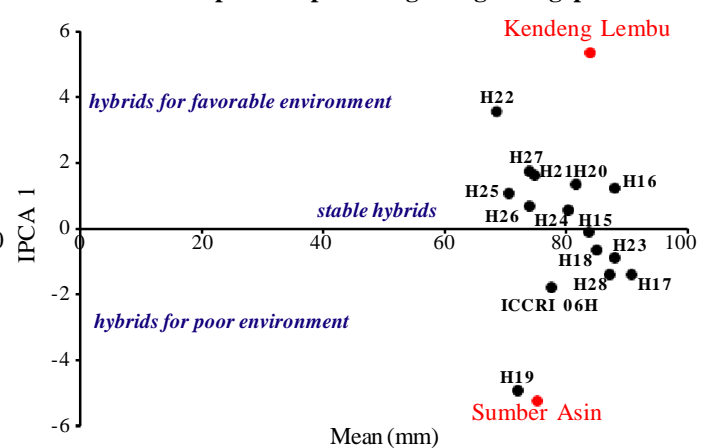

AMMI 1 Biplot for flowering intensity

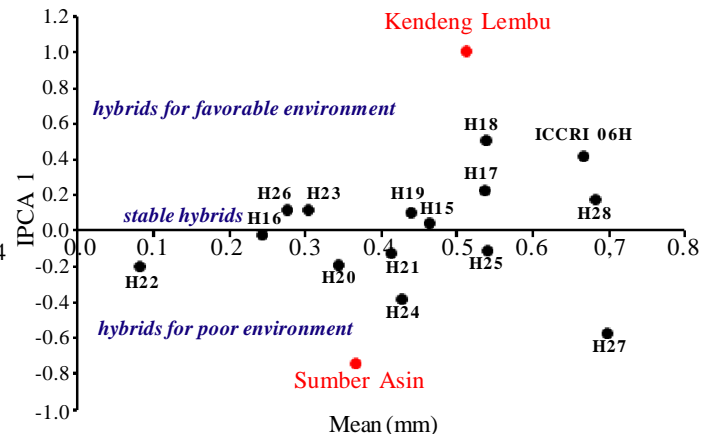

Figure 1. AMMI Biplot analysis of 15 hybrids tested in two plantations (Kendeng Lembu and Sumber Asin) based on tree diameter, percentage of growing plants, flush and flower intencity (Description: H15 = ICCRI 03 x KW 617; H16 = ICCRI 03 x KW 516; H17 = ICCRI 03 x Sulawesi 3; H18 = ICCRI 03 x Sulawesi 1; H19 = KW 617 x ICCRI 03; H20 = KW 617 x KW 516; H21 = KW 617 x Sulawesi 3; H22 = KW 617 x Sulawesi 1; H23 = KW 516 x ICCRI 03; H24 = KW 516 x KW 617; H25 = KW 516 x KW 617; H26 = KW 516 x Sulawesi 1; H27 = Sulawesi 3 x KKM 22; $\mathrm{H} 28=\mathrm{KKM} 22 \times$ Sulawesi 3

\section{CONCLUSION}

The basis for hybrid selection is the preliminary growth of the cocoa plant during the 2015 El Nino in Indonesia. Based on the drought-tolerant hybrid selection, the stable cocoa hybrids are ICCRI03 x KW 617; KW 516 x KW 617; and KW 516 x Sulawesi 01, and the ones adaptive to drought are KW 617 x KW 516; KW 516 x KW 617; and Sulawesi 3 x KKM 22. The potential planting material for droughtresistant cocoa hybrids are KW 617, KW 516, and Sulawesi 3.

\section{ACKNOWLEDGEMENTS}

The writers would like to thank Director of the Indonesian Coffee and Cocoa Research Institute and the Manager of Kendeng Lembu PTPN XII Plantation for giving permission to use some of the facilities as well as Rudi Hartoyo, Sukarmin, and Arik Ermawan for their assistance during the data collection. 


\section{REFERENCES}

Amedie, F.A. (2013). Impacts of Climate Change on Plant Growth, Ecosystem Services, Biodiversity, and Potential Adaptation Measure. Department of Biological and Environmental Science University of Gothenburg. Sweden.

Amos T.T. \& O.A. Thompson (2015). Climate change and the cocoa production in the tropical rain forest ecological zone of Ondo State, Nigeria. Journal of Environment and Earth Science, 5, 36-41.

Anita-Sari, I. \& A.W. Susilo (2012). Keberhasilan sambungan pada beberapa jenis batang atas dan famili batang bawah kakao (Theobroma cacao L.). Pelita Perkebunan, 28, $72-81$.

Anjum, S.A.; X. Xie; L. Wang; M.F. Saleem; C. Man \& W. Lei (2011). Morphological, physiological and biochemical responses of plants to drought stress. African Journal of Agricultural Research, 6, 2026-2032.

BMKG (2015). Kekeringan 2015. Press Release. Badan Metereologi dan Geofisika. Jakarta.

Baye, M.T.; T. Abebe \& R.A. Wilke (2011). Genotype-environment interactions and their translational impication. Personalized Medicine, 8, 59-70.

Carr, M.K.V.\& G. Lockwood (2011). The water relations and irrigation requirements of cocoa (Theobroma cacao L.) : A Review. Experimental Agriculture, 47, 653-676.

Ditjenbun (2015). Statistik Perkebunan Indonesia Kakao 2014-2016. Direktorat Jenderal Perkebunan, Jakarta.

Farooq, M.; A. Wahid; N. Kobayashi; D. Fujita \& S.M.A. Basra (2009). Plant drought stress: effects, mechanisms and management. Agronomy for Sustainable Development, 29, 185-212.

Floris, M.; H. Mahgoub; E. Lanet; C. Robaglia $\&$ B. Menand (2009). Post-transcriptional regulation of gene expression in plants during abiotic stress. International Journal of Molecular Sciences, $10,3168-3185$.

Hauke, J. \& T. Kossowski (2011). Comparison of values of Pearson's and Spearman's correlation coefficients on the same sets of data. Questiones Geographicae, 30, 87-93.

Mc Dermott, B.\& R. Coe (2012). An Easy Introduction to Biplots for Multi-Environment Trials. Statistical Service Centre, University of Reading, UK.

Mukaka, M.M. (2012). A guide to appropriate use of correlation coefficient in medical research. Malawi Medical Journal, 24, 69-71.

Muthuramu, S.; S. Jebaraj \& M. Gnanasekaran (2011). AMMI biplot analysis for drought tolerance in rice (Oryza sativa L.). Research of Agricultural Sciences, 2, 98-100.

Nohong, B.\& S. Nompo (2015). Effect of water stress on growth, yield, proline and soluble sugars contents of Signal grass and Napier grass species. AmericanEurasian Journal of Sustainable Agriculture, 9, 14-21.

Oyekale A.S.; M.B. Bolaji \& O.W. Olowa (2009). The effects of climate change on cocoa production and vulnerability assessment in Nigeria. Agricutural Journal, $4,77-85$.

Paez-Garcia, A.; C.M. Motes; W.R. Scheible; R. Chen; E.B. Blancaflor \& M.J. Monteros (2015). Root traits and phenotyping strategies for plant improvement. Plants, 4, 334-355.

Prabha, C.; A. Singh \& Rolly (2012). Induction of haploids and double haploids in Chlorophytum borivilianum Santa Pau \& Fernandes: An endangered medicinal crop. International Conference on Biological and Life Sciences, 40, $1-5$.

Rashidi, M.; E. Farshadfar \& M.M. Jowkar (2013). AMMI analysis of phenotypic stability in chickpea genotypes over stress and 
non-stress environment. International Journal of Agriculture and Crop Sciences, 5, 253-260.

Wahyudi, T.; Misnawi \& Pujiyanto (2015). Kakao: Sejarah, Botani, Prosedur Produksi, Pengolahan, dan Perdagangan. Gadjah Mada University Press, Yogyakarta.

Susilo, A.W. (2011). Analisis stabilitas dayahasil beberapa hibrida unggul harapan kakao (Theobroma cacao L.) pada lokasi tumbuh berbeda. Pelita Perkebunan, 27, 168-180.

Susilo, A.W.; I.A. Sari; B. Setyawan; E. Sulistyowati; F. Nur'aini \& N.A. Febrianto (2016). Perakitan Varietas Unggul Kakao (Theobroma cacao L.) Tahan Penyakit Vascular Streak Dieback (Ceratobasidium theobromae) dan Penyakit Busuk Buah (Phytophthora palmivora) yang Adaptif pada Kondisi Lahan Marginal
Kering. Laporan Penelitian Rutin Pusat Penelitian Kopi dan Kakao Indonesia. Jember.

Suwarto \& Nasrullah (2014). Analysis of genotype $\mathrm{x}$ environment interaction effect and yield stability on improved rice genotypes in Central Java using graphical GGE-Biplot method. Research Journal of Pharmaceutical, Biological and Chemical Sciences, 5, 197-206.

Thangavel, P.; A. Anandan \& R. Eswaran (2011). AMMI analysis to comprehend genotype-by-environment ( $\mathrm{G} \times \mathrm{E}$ ) interactions in rainfed grown mungbean (Vigna radiata L.). Australian Journal of Crop Science, 5, 1767-1775.

Torbenson, M.C.A. (2015). Geomorphological Techniques: Dendrochronology. Department of Geosciences, University of Arkansas, USA. 